\title{
PENGARUH JUMLAH PENDUDUK MISKIN TERHADAP PENGALOKASIAN BELANJA PENDIDIKAN DENGAN ALOKASI DANA DESA (ADD) DAN DANA DESA (DD) SEBAGAI VARIABEL MODERATING TAHUN 2017 (Studi Empiris di Desa-Desa Kabupaten Wonogiri)
}

\author{
Rucika Dewi Febriyanti ${ }^{1}$ dan Andy Dwi Bayu Bawono ${ }^{2}$ \\ Fakultas Ekonomi dan Bisnis, Universitas Muhammadiyah Surakartal , Fakultas Ekonomi \\ dan Bisnis, Universitas Muhammadiyah Surakarta ${ }^{2}$ \\ cikha.dhewie96@gmail.com ${ }^{1}$,andy.bawono@ums.ac.id ${ }^{2}$
}

\begin{abstract}
This study aims to analyze the influence of the Number of People Living in Poverty on the allocation of Education Expenditure, by using Village Fund Allocation (ADD) and Village Fund (DD) as the moderating variables. Based on the Law number 20/2003 on Education National System, the budget allocation for Education sector has an important role to improve the welfare of village communities in the village goverment system. The population used in this study is the entire villages (around 298 Villages) in the Wonogiri District. the purposive sampling in accordance with certain criterias was also used as a sampling method resulting to 196 villages were obtained for analysis. Multiple linear regression analysis and analysis of moderating variables were used for the examination of data. The results of this study indicate that the number of People Living in Poverty has a negatively influence to the allocation of Education Expenditure. Further, the variables of Village Fund Allocation (ADD) an Village Funds (DD) were not able to moderate the influence of People Living in Poverty on Education Expenditures.

Keywords: number of people living in poverty, add, dd, and allocation of education expenditure
\end{abstract}

\section{PENDAHULUAN}

Negara Indonesia memiliki sebuah Kabupaten/Kota yang dibawahnya terdiri atas kelurahan dan desa yang mempunyai potensi yang berbeda-beda. Desa sendiri merupakan bagian terkecil dalam struktur pemerintahan di Indonesia yang bertugas dalam memajukan dan meningkatkan kesejahteraan masyarakat desa (Syamsi, 2014).

Muliza, dkk (2017) mengatakan dibutuhkan sumber daya manusia yang berkualitas dalam meningkatkan kesejahteraan masyarakat, sehingga diperlukannya sarana dan prasarana untuk mendukung terciptanya masyarakat 
yang sejahtera. Salah satunya yaitu dalam sektor pendidikan. Aspek pendidikan diperlukan untuk mendukung pembangunan yang mendasar dalam setiap wilayah. Akan tetapi dalam mendukung adanya sektor pendidikan yang berkuallitas diperlukannya anggaran.

Di era otonomi daerah sekarang diharapkan bisa timbul kemandirian desa yang dapat membantu dalam meningkatkan kualitas pelayanan publik dalam berbagai sektor yang berkembang atau berpotensi yang dapat menjadi sumber pendapatan bagi desa. Peran Pemerintah Desa sangat dibutuhkan dalam meningkatkan pendapatan desa dan memberikan kontribusi dalam peningkatan pendapatan daerah dan nasional (Pelealu, 2013).

Undang-Undang No. 6 Tahun 2014 tentang Desa mencantumkan sebuah pengaturan mengenai keuangan desa dan aset desa yang dibahas di pasal 72 ayat 1 huruf $b$ yang menyatakan bahwa sumber pendapatan desa berasal dari Anggaran Pendapatan dan Belanja Negara. Kemandirian desa dalam pengelolaan anggaran yang digunakan untuk mengoptimalkan sumber pendapatan desa adalah Pendapatan Asli Desa (PADes).

Keuangan desa merupakan hak dan kewajiban yang dimiliki desa baik berupa barang atau jasa. Menurut Siburian, dkk (2014) hak dan kewajiban dapat menimbulkan pendapatan, belanja dan keuangan yang terdapat dalam Anggaran Pendapatan dan Belanja Desa (APBDesa). Anggaran Pendapatan dan Belanja Desa (APBDesa) merupakan salah satu hal penting untuk menentukan dalam mewujudkan kepemerintahan yang baik dalam tingkat desa.. Hal ini terlihat dari persoalan pendidikan yang terhambat karena kemiskinan. Masalah kemiskinan menjadi persoalan mendasar yang menjadi pusat perhatian pemerintah karena cukup sulit untuk mengatasinya. Hal tersebut diperparah dengan banyaknya rumah tangga yang berada di sekitar garis kemiskinan.

Kabupaten Wonogiri merupakan salah satu kabupaten di Provinsi Jawa Tengah yang memilki jumlah penduduk miskin pada tahun 2017 sebanyak 12.404 ribu jiwa dengan presentase 12.90 dengan garis kemiskinan 284.710 https://wonogirikab.bps.go.id/. Kemiskinan sendiri adalah ketidakmampuan dalam memenuhi standar hidup minimum, sehingga permasalahan standar hidup yang rendah akan mempengaruhi persoalan pendidikan yang akan menyebabkan banyaknya pengangguran dikarenkan rendahnya sumber daya manusia yang dimiliki.

Seperti yang telah dipaparkan di atas, pemerintah telah meluncurkan berbagai program untuk meningkatkan pendidikan di desa. Salah satunya adalah program dana desa. Dana Desa terbukti telah menghasilkan sarana/prasarana yang berguna bagi masyarakat, salah satunya yaitu terbangunnya 14.957 unit PAUD dalam periode 2015-2016. Jadi Dana Desa berperan penting dalam pengurangan jumlah penduduk miskin selain itu Dana Desa juga berperan dalam meningkatkan kesejahteraan masyarakat desa yaitu salah satunya melalui program pendidikan.

Selain Dana Desa sumber pendapatan desa yang lain adalah Alokasi Dana Desa. ADD tersebut diberikan guna untuk membiayai Program Pemerintah Desa 
dalam melaksanakan kegiatan penyelenggaraan pemerintahan dan pelaksanaan pembangunan serta pemberdayaan masyarakat, salah satunya yaitu menanggulangi kemiskinan dan mengurangi kesenjangan ekonomi.

Berdasarkan UU yang mengatur tentang Desa menjelaskan bahwa desa memilki peran penting dalam membangun cita-cita kemerdekaan yang terdapat dalam Undang-Undang Republik Indonesia tahun 1945. Pada penelitian sebelumnya hanya dilakukan pada level Daerah (Kabupaten/Kota) saja. Sedangkan penelitian pada level desa masih sedikit peneliti yang meneliti mengenai Desa. Sehingga dalam penelitian ini peneliti tertarik meneliti tentang desa khususnya tentang anggaran desa (APBDesa).

Berdasarkan uraian diatas, penulis tertarik membuat judul yaitu,

"PENGARUH JUMLAH PENDUDUK MISKIN TERHADAP
PENGALOKASIAN BELANJA PENDIDIKAN DENGAN ALOKASI DANA DESA (ADD) DAN DANA DESA (DD) SEBAGAI VARIABEL MODERATING TAHUN 2017 (STUDI EMPIRIS DI DESA-DESA SEKABUPATEN WONOGIRI)".

\section{TINJAUAN PUSTAKA DAN PENGEMBANGAN HIPOTESIS}

\section{Landasan Teori}

\section{Desentralisasi Desa}

Menurut Undang-Undang No. 23 Tahun 2014 Desentralisasi merupakan bentuk penyerahan urusan pemerintahan oleh Pemerintah Pusat kepada daerah otonom berdasarkan asas otonomi. Desentralisasi pada dasarnya yaitu penyerahan kekuasaan atau wewenang di bidang tertentu secara vertikal dari instansi atau lembaga yang lebih tinggi kepada instansi fungsionaris bawahannya.

\section{Kemandirian Desa}

Menurut Undang-Undang No. 6 Tahun 2014 tentang desa, kemandirian desa ialah suatu proses yang dilakukan oleh pemerintah desa dan masyarakat desa untuk melaksanakan kegiatan dalam memenuhi kebutuhan dengan kemampuannya sendiri.

\section{Desa}

Dalam Undang-Undang No. 6 Tahun 2014 bahwa Desa merupakan kesatuan masyarakat hukum yang mempunyai batas wilayah yang berwenang untuk mengatur urusan pemerintahan untuk kepentingan masyarakat setempat berdasarkan prakarsa masyarakat, hak asal usul, dan/atau hak tradisional yang diakui dan dihormati dalam sistem pemerintahan Negara Kesatuan Republik Indonesia.

\section{Keuangan Desa}

Berdasarkan Undang-Undang No. 6 Tahun 2014 pasal 1 tentang desa, keuangan desa adalah semua hak dan kewajiban desa yang dapat dinilai dengan uang serta segala sesuatu berupa uang dan barang yang berhubungan dengan pelaksanaan hak dan kewajiban. Kepala desa sebagai pemegang kekuasaan 
pegelolaan keuangan desa memberikan sebagian kewenangan kepada perangkat desa yang ditunjuk atau Pelaksana Teknis Pengelolaan keuangan Desa (PTPKD).

\section{Kemiskinan}

Kemiskinan adalah ketidakmampuan untuk memenuhi standar hidup minimum. Permasalahan standar hidup yang rendah berkaitan dengan jumlah pendapatan yang sedikit, perumahan yang kurang layak, kesehatan dan pelayanan kesehatan yang buruk, tingkat pendidikan masyarakat yang rendah sehingga berakibat pada rendahnya sumber daya manusia dan banyaknya pengangguran.

\section{Penduduk Miskin}

Penduduk Miskin merupakan penduduk yang memiliki rata-rata pengeluaran perkapita perbulan dibawah garis kemiskinan. Persentase penduduk miskin terhadap jumlah penduduk indonesia terus mengecil akibat dari terus menurunnya jumlah penduduk miskin.

\section{Alokasi Belanja Desa Bidang Pendidikan}

Belanja desa diprioritaskan untuk memenuhi kebutuhan pembangunan yang disepakati dalam Musyawarah Desa dan sesuai dengan prioritas pemerintah daerah kabupaten/kota, serta pemerintah daerah provinsi. Upaya untuk menunjang pelayanan dasar khususnya pendidikan desa juga memberikan peran aktif melalui alokasi anggaran bidang pendidikan pada APBDes-nya. Menurut Peraturan Pemerintah No. 43 Tahun 2014 menyatakan bahwa desa memiliki kewenangan lokal khususnya dalam belanja bidang pendidikan yaitu kewenangan dalam pengembangan dan pembinaan sanggar seni dan belajar selain itu pengelolaan perpustakaan Desa dan taman bacaan.

\section{Alokasi Dana Desa}

Peraturan Pemerintah No. 47 Tahun 2015 mengenai Peraturan Pelaksanaan Undang-Undang No 6 Tahun 2014 Tentang Desa, menyatakan bahwa Alokasi Dana Desa selanjutnya disingkat ADD, adalah dana perimbangan yang diterima Kabupaten/Kota dalam anggaran pendapatan dan belanja daerah Kabupaten atau kota setelah dikurangi. Dana Alokasi Khusus. Alokasi dana desa dalam APBDesa harus memperhatikan presentase anggaran, penggunaan dana untuk penyelenggaraan Pemerintah Desa, pelaksanaan pembangunan desa, pembinaan kemasyarakatan desa, dan pemberdayaan masyarakat desa paling sedikit $70 \%$ dari jumlah anggaran belanja desa, dan paling banyak 30\% dari jumlah anggaran belanja desa.

\section{Dana Desa}

Menurut Peraturan Pemerintah No. 47 Tahun 2015 mengenai Peraturan Pelaksanaan Undang-Undang No. 6 Tahun 2014 Tentang Desa, Dana Desa (DD) merupakan dana yang bersumber dari anggaran pendapatan dan belanja Negara yang diperuntukan bagi desa yang ditransfer melalui anggaran pendapatan dan belanja daerah kabupaten/kota dan digunakan untuk membiayai penyelenggaraan pemerintahan, pelaksanaan pembangunan, pembinaan kemasyarakatan, dan pemberdayaan masyarakat. 


\section{Penelitian Terdahulu}

Penelitian yang dilakukan oleh Ayu Miftakhul Janah (2018) berjudul Analisis Flypaper Effect pada Pendapatan Asli Desa (PaDesa), Alokasi Dana Desa (ADD), dan Dana Desa (DD) terhadap Belanja Desa Tahun 2017 (Studi Empiris di Desa-Desa Se-Kabupaten Wonogiri). Hasil penelitian ini menunjukkan bahwa variabel pendapatan asli desa, alokasi dana desa dan dana desa berpengaruh positif dan signifikan terhadap belanja desa serta terjadi flypaper effect pada pengelolaan keuangan di desa-desa Se-Kabupaten Wonogiri pada tahun 2017.

Penelitian yang dilakukan oleh Mardiana Luvitasari (2018) berjudul Pengaruh Pendapatan Asli Desa (PaDesa), Dana Desa (DD), Alokasi Dana Desa (ADD), Bagi Hasil Pajak dan Retribusi (BHPR), dan Jumlah Murid PAUD terhadap Alokasi Belanja Desa Bidang Pendidikan Tahun 2017 (Studi Empiris di Desa-Desa Se-Kabupaten Wonogiri). Hasil peneltian ini menunjukkan bahwa koefisien determinasi diperoleh nilai sebesar 0,032 atau 3,2\%. Hal ini berarti bahwa variasi variable Alokasi Belanja Desa Bidang Pendidikan dapat dijelaskan oleh variable PADesa, DD, ADD, BHPR, dan JML_ANK_PA (Jumlah Murid PAUD), sedangkan sisanya 96,8\% dijelaskan oleh faktor-faktor lain diluar model yang diteliti. Hasil uji PADesa berpengaruh positif dan signifikan terhadap Alokasi Belanja Desa Bidang Pendidikan. Sedangkan DD, ADD, BHPR, dan Jumlah Murid Paud tidak berpengaruh signifikan terhadap Alokasi Belanja Desa Bidang Pendidikan.

Penelitian yang dilakukan oleh Ummu Habibah (2017) berjudul Pengaruh Pendapatan Asli Desa (PaDesa), Dana Desa (DD), Alokasi Dana Desa (ADD), dan Bagi Hasil Pajak dan Retribusi (BHPR) terhadap Belanja Desa Bidang Pendidikan (Studi Empiris di Desa-Desa Se-Kabupaten Wonogiri). Hasil peneltian ini menunjukkan bahwa koefisien determinasi diperoleh nilai sebesar 0,051. Hal ini berarti bahwa 5,1\% variasi variabel belanja desa bidang pendidikan dapat dijelaskan oleh PADesa, DD, ADD, dan BHPR, sedangkan sisanya 94,9\% dijelaskan oleh faktor-faktor lain diluar model yang diteliti. Hasil uji secara simultan menunjukan bahwa PADesa, DD, ADD, dan BHPR berpengaruh secara signifikan terhadap belanja desa bidang pendidikan. Sedangkan hasil pengujian secara parsial menunjukan bahwa PADesa, ADD, dan BHPR tidak berpengaruh secara signifikan terhadap belanja desa bidang pendidikan, akan tetapi DD berpengaruh secara signifikan terhadap belanja desa bidang pendidikan.

Penelitian yang dilakukan oleh Muhammad Nur (2015) berjudul Pengaruh Pendapatan Asli Daerah, Dana Alokasi Umum, dan Dana Alokasi Khusus terhadap Belanja Daerah di Sulawesi Selatan. Hasil penelitian ini menunjukkan PAD dan DAK secara parsial berpengaruh signifikan terhadap Belanja Daerah sedangkan DAU tidak berpengaruh signifikan terhadap Belanja Daerah. 
Penelitian yang dilakukan oleh Ramadha Puspita Sari (2014) berjudul Pengaruh Pendapatan Asli Daerah (PAD), Dana Alokasi Umum (DAU) dan Dana Alokasi Khusus (DAK) terhadap Belanja Daerah (Studi Kasus pada Pemerintah Daerah Kabupaten/Kota di Provinsi Jawa Tengah dan DIY). Hasil pengujian penelitian dapat disimpulkan bahwa PAD, DAU dan DAK berpengaruh signifikan terhadap belanja daerah.

\section{METODE PENELITIAN}

\section{Jenis Penelitian}

Jenis penelitian ini bersifat kuantitatif. Menurut Kuncoro, (2013:145) penelitian kuantitatif merupakan data yang diukur dalam satuan skala numerik (angka), skor, dan analisisnya menggunakan statistik untuk menganalisis suatu hipotesis dan memerlukan beberapa alat analisis. Bila serangkaian observasi atau pengukuran data dalam angka-angka hasil observasi atau pengukuran sedemikian itu dinamakan data kuantitatif.

\section{Populasi, Sampel, dan Teknik Pengambilan Sampel}

Populasi dalam penelitian ini sebanyak 298 Desa di seluruh Kabupaten Wonogiri. Teknik pengambilan sampel menggunakan purposive sampling dengan kriteria sebagai berikut (1) Desa-desa se-Kabupaten Wonogiri yang telah mengumpulkan Laporan Realisasi Anggaran APBDes selama tahun 2017, (2) Desa-desa yang melakukan Belanja Desa Bidang Pendidikan, dan (3) Desa-desa yang terdaftar dalam Basis Data Terpadu Tim Nasional Percepatan Penanggualangan Kemiskinan tahun 2015. dengan teknik analisis data menggunakan analisis regresi linear berganda.

\section{Data, sumber data, dan teknik pengumpulan data}

Data yang dikumpulkan dalam penelitian ini adalah data sekunder. Menurut Darmawan (2013), data sekunder merupakan data yang diperoleh dari dokumendokumen yang berasal dari instansi yang bersangkutan. Data sekunder ini berupa Laporan Realisasi APBDes Pemerintah Wonogiri tahun 2017 mengenai Belanja Pendidikan, Dana Desa (DD), Alokasi Dana Desa (ADD) dan Jumlah Penduduk Miskin dari TNP2K. Metode pengumpulan data yang digunakan pada penelitian ini adalah metode dokumentasi.

\section{Definisi Operasional Variabel}

\section{Variabel Dependen}

\section{Belanja Pendidikan}

Berdasarkan Permendagri No. 113 Tahun 2014 Tentang Pengelolaan Keuangan Desa, belanja desa adalah semua pengeluaran dari rekening desa yang merupakan kewajiban desa dalam 1 tahun anggaran yang tidak akan diperoleh kembali pembayarannya. 


\section{Variabel Independen}

\section{Jumlah Penduduk Miskin}

Masalah kemiskinan yang dihadapi negara berkembang untuk saat ini memang kompleks. Untuk mengukur kemiskinan, BPS menggunakan konsep kemampuan memenuhi kebutuhan dasar (basic needs approach). Penduduk Miskin adalah penduduk yang memiliki rata-rata pengeluaran perkapita perbulan dibawah garis kemiskinan.

\section{Variabel Moderating}

\section{Alokasi Dana Desa (ADD)}

Peraturan Pemerintah No. 43 Tahun 2014, menyatakan bahwa Alokasi Dana Desa (ADD) adalah dana perimbangan yang diterima kabupaten/kota dalam APBD kabupaten/kota setelah dikurangi dana alokasi khusus. Pemberian alokasi dana desa untuk melaksanakan otonomi desa agar dapat meningkatkan kesejahteraan masyarakat desa serta menyelenggarakan pembangunan dan pertumbuhan wilayah-wilayah desa.

\section{Dana Desa (DD)}

Berdasarkan Peraturan Pemerintah No. 43 Tahun 2014, dana desa adalah dana yang bersumber dari Anggaran Pendapatan dan Belanja Desa (APBDesa) yang diperuntukkan bagi desa yang ditransfer melalui anggaran pendapatan dan belanja daerah kabupaten/kota dan digunakan untuk membiayai penyelenggaraan pemerintahan, pelaksanaan pembangunan, pembinaan kemasyarakatan, dan pemberdayaan masyarakat.

\section{Metode Analisis Data}

Metode analisis data yang digunakan dalam penelitian ini adalah Moderated Regression Analysis (MRA) dengan bantuan komputer melalui program IBM SPSS 21 for windows.. MRA merupakan aplikasi dari regresi linear berganda dimana dalam persamaannya mengandung unsur interaksi (perkalian dua/lebih variabel independen) yang dinyatakan dalam persamaan berikut:

1. $\mathrm{BP}=\alpha+\mathrm{b}_{1} \mathrm{JPM}+e$

2. $\mathrm{BP}=\alpha+\mathrm{b}_{1} \mathrm{JPM}+\mathrm{b}_{2} \mathrm{ADD}+\mathrm{b}_{3} \mathrm{JPM} * \mathrm{ADD}+e$

3. $\mathrm{BP}=\alpha+\mathrm{b}_{1} \mathrm{JPM}+\mathrm{b}_{2} \mathrm{DD}+\mathrm{b}_{3} \mathrm{JPM} \mathrm{M}^{*} \mathrm{DD}+e$

$$
\begin{aligned}
& \text { Keterangan: } \\
& \alpha \quad=\text { constant } \\
& \mathrm{BP}=\text { Alokasi Belanja Pendidikan } \\
& \mathrm{JPM}=\text { Jumlah Penduduk Miskin } \\
& \mathrm{ADD}=\text { Alokasi Dana Desa (ADD) } \\
& \mathrm{DD}=\text { Dana Desa (DD) } \\
& e \quad=\text { error term, yaitu tingkat kesalahan penduga dalam penelitian }
\end{aligned}
$$




\section{HASIL PENGUJIAN HIPOTESIS DAN PEMBAHASAN}

\section{Uji Asumsi Klasik}

\section{Uji Normalitas}

Menurut Ghozali (2011), Uji Normalitas merupakan sebuah uji yang dilakukan dengan tujuan untuk menilai apakah dalam model regresi, variabel terikat dan variabel bebas memiliki distribusi normal.

Penelitian ini memiliki sampel sebanyak 176 desa, sehingga menggunakan model Central Limit Theorem (CLT) dalam pengujian ini, karena CLT memiliki ketentuan jika sampel yang diuji banyaknya lebih dari 30 angka $(\mathrm{n} \geq 30)$ maka sudah dapat diasumsikan berdistribusi normal, sehingga berdasarkan sampel penelitian sebesar 176, maka sampel tersebut bisa dikatakan sebagai sampel berdistribusi normal (Lind, 2014: 300-301 )

\section{Uji Multikolinearitas}

Menurut Ghozali (2011), Uji Multikolinearitas ini bertujuan untuk menguji apakah model regresi ditemukan adanya korelasi antara variabel bebas (independent). Untuk mengetahui terjadinya multikolinaritas dapat dilihat dengan cara melihat nillai tolerance. Jika nilai tolerance $>0,10$ maka tidak terjadi multikolinearitas terhadap data yang di uji. Sebaliknya jika nilai tolerance $<0,10$ maka terjadi multikolinearitas terhadap data yang di uji. Cara kedua dengan melihat nilai VIF, Jika nilai VIF $<10,00$ maka artinya tidak terjadi multikolinearitas sedangkan jika nilai VIF > 10,00 maka terjadi multikolineritas. Hasil Uji Multikolinearitas dapat di lihat pada tabel di bawah :

\section{Tabel 1. Hasil Uji Multikolinearitas}

Variabel Collinearity Statistics

\begin{tabular}{lrr} 
& \multicolumn{3}{c}{ Tolerance } & VIF \\
\hline Jumlah Penduduk Miskin & 0,982 & 1,019 \\
Alokasi Dana Desa & 0,982 & 1,019 \\
\hline
\end{tabular}

Dependent Variable: Belanja Pendidikan

\section{Tabel 2. Hasil Uji Multikolinearitas}

Variabel Collinearity Statistics

\begin{tabular}{lrr} 
& Tolerance & VIF \\
\hline Jumlah Penduduk Miskin & 0,759 & 1,318 \\
Dana Desa & 0,759 & 1,318 \\
\hline
\end{tabular}

Dependent Variable: Belanja Pendidikan

Dilihat dari tabel di atas ditemukan hasil uji multikolinearitas dalam 2 (dua) persamaan yaitu :

\section{Tabel 1}

Variabel JPM*ADD memiliki nilai tolerance $0,982<0,10$ dan nilai VIF sebesar $1,019<10,00$. Disimpulkan bahwa model regresi tidak terjadi multikolinearitas. 


\section{Tabel 2}

Variabel JPM*DD memiliki nilai tolerance $0,759<0,10$ dan nilai VIF sebesar $1,318<10,00$. Jadi dapat disimpulkan bahwa model regresi tidak terjadi multikolinearitas.

\section{Uji Heteroskedastisitas}

Pengujian ini bertujuan untuk menilai apakah ada ketidaksamaan varian dari residual untuk semua pengamatan yang terdapat pada model regresi linear. Jika terdapat variancedan residual satu pengamatan ke pengamatan lain tetap, maka disebut homosdastisitas (Ghozali, 2011). Untuk menguji heteroskedastisitas, penelitian ini menggunakan uji glejser. Ketentuan yang terdapat pada uji glejser sebagai berikut:

1. Jika probability value $<0,05$ maka terjadi heteroskedastisitas

2. Jika probability value $>0,05$ maka tidak terjadi heteroskedastisitas.

Tabel 3. Hasil Uji Heteroskedastisitas

\begin{tabular}{lccl}
\multicolumn{1}{c}{ Variabel } & T & Sig & Keterangan \\
\hline Jumlah Penduduk & & & \\
Miskin & $-0,016$ & 0,987 & Tidak terjadi heteroskedastisitas \\
Dana Desa & 0,641 & 0,522 & Tidak terjadi heteroskedastisitas \\
JPMxADD & $-0,277$ & 0,782 & Tidak terjadi heteroskedastisitas \\
\hline
\end{tabular}

Berdasarkan tabel di atas diketahui uji glejser yang dilakukan untuk persamaan 1 tidak terjadi heteroskedastisitas karena memiliki nilai signifikansi lebih dari 0,05 .

Tabel 4. Hasil Uji Heteroskedastisitas

\begin{tabular}{|c|c|c|c|}
\hline Variabel & $\mathbf{T}$ & Sig & Keterangan \\
\hline Penduduk & & & \\
\hline Miskin & $-1,438$ & 0,152 & Tidak terjadi heteroskedastisitas \\
\hline Dana Desa & $-1,541$ & 0,125 & Tidak terjadi heteroskedastisitas \\
\hline JPMxDD & 1,307 & 0,193 & Tidak terjadi heteroskedastisitas \\
\hline
\end{tabular}

Sumber: Data diolah peneliti, 2018

Berdasarkan tabel di atas diketahui uji glejser pada persamaan 2 tidak terjadi heteroskedastisitas karena memiliki nilai signifikansi lebih dari 0,05.

\section{Analisis Regresi Linear Berganda}

Analisis regresi linear berganda ini digunakan untuk menguji pengaruh Jumlah Penduduk Miskin terhadap Pengalokasian Belanja Pendidikan dan untuk menguji apakah Alokasi Dana Desa (ADD) dan Dana Desa (DD) memoderasi hubungan antara Jumlah Penduduk Miskin dengan Pengalokasian Belanja Pendidikan.

Dalam penelitian ini terdapat 3 (tiga) persamaan regresi linear berganda seperti tabel 5 . 
Tabel 5. Hasil Uji Regresi Berganda

\begin{tabular}{|c|c|c|c|c|}
\hline \multirow[t]{2}{*}{ Variabel } & \multicolumn{2}{|c|}{ Unstandardized Coefficients } & \multirow[t]{2}{*}{$\mathrm{T}$} & \multirow[t]{2}{*}{ Sig. } \\
\hline & $\mathrm{B}$ & Std. Error & & \\
\hline (Constant) & $3,02 \mathrm{E}+07$ & 4049586,339 & 7,468 & 0,000 \\
\hline Jumlah Penduduk Miskin & $-25038,896$ & 8855,993 & $-2,827$ & 0,005 \\
\hline
\end{tabular}

Berdasarkan persamaan 1 hasil pengujian dapat dirumuskan persamaan regresi linear berganda sebagai berikut :

$\mathrm{BP}=30240000-25038,896 \mathrm{JPM}+e$

Tabel 6. Hasil Uji Regresi Berganda

\begin{tabular}{lrrrr}
\hline \multirow{2}{*}{ Variabel } & \multicolumn{2}{c}{ Unstandardized Coefficients } & \multicolumn{1}{l}{ T } & \multirow{2}{*}{ Sig. } \\
\cline { 2 - 3 } & \multicolumn{1}{c}{$\mathrm{B}$} & \multicolumn{1}{c}{ Std. Error } & & \\
\hline (Constant) & $1,531 \mathrm{E} 7$ & $2,73 \mathrm{E} 7$ & 0,561 & 0,575 \\
Jumlah Penduduk Miskin & 24582,746 & 86575,455 & 0,284 & 0,777 \\
Alokasi Dana Desa & 0,032 & 0,058 & 0,550 & 0,583 \\
JPMxADD & 0,000 & 0,000 & $-0,578$ & 0,564 \\
\hline
\end{tabular}

Dependent Variable: Belanja Pendidikan

Berdasarkan persamaan 2 hasil pengujian dirumuskan persamaan regresi linear berganda sebagai berikut :

$\mathrm{BP}=15310000+24582,746 \mathrm{JPM}+0,032 \mathrm{ADD}+0,000 \mathrm{JPM} * \mathrm{ADD}+e$

Tabel 7. Hasil Uji Regresi Berganda

\begin{tabular}{lrrrr}
\hline \multirow{2}{*}{ Variabel } & \multicolumn{2}{c}{ Unstandardized Coefficients } & \multicolumn{1}{l}{ T } & \multirow{2}{*}{ Sig. } \\
\cline { 2 - 3 } & \multicolumn{1}{c}{$\mathrm{B}$} & \multicolumn{1}{c}{ Std. Error } & & \\
\hline (Constant) & 160500000 & 144000000 & 1,115 & 0,266 \\
Jumlah Penduduk Miskin & $-177211,476$ & 182832,042 & $-0,969$ & 0,334 \\
Dana Desa & $-0,166$ & 0,184 & $-0,903$ & 0,368 \\
JPMxDD & 0,000 & 0,000 & 0,844 & 0,400 \\
\hline
\end{tabular}

Dependent Variable: Belanja Pendidikan

Berdasarkan persamaan 3 hasil pengujian dapat dirumuskan persamaan regresi linear berganda sebagai berikut :

$\mathrm{BP}=160500000-177211,476 \mathrm{JPM}-0,166 \mathrm{DD}+0,000 \mathrm{JPM}{ }^{*} \mathrm{DD}+e$ 


\section{Uji Hipotesis}

\section{Uji Koefisien Determinasi (R2)}

Terdapat 3 (tiga) persamaan hasil pengujian $\left(\mathrm{R}^{2}\right)$ dilihat pada tabel $8-10$. Hasil uji $\mathrm{R}^{2}$ pada ketiga tabel tersebut menunjukkan perbandingan determinasi dengan adjusted- $\mathrm{R}^{2}$. Persamaan pertama yaitu diketahui bahwa Jumlah Penduduk Miskin (JPM) nilai (R2) dalam analisis regresi linear berganda diperoleh angka koefisien diterminasi dengan adjusted-R2 sebesar 0,038. Hal ini berarti bahwa 3,8\% variasi variabel Belanja Pendidikan dapat dijelaskan oleh variabel Jumlah Penduduk Miskin (JPM), sedangkan 96,2\% dijelaskan oleh faktor-faktor lain diluar model yang diteliti.

Tabel 8. Uji Koefisien Determinasi (R2)

\begin{tabular}{clll} 
R & R Square & Adjusted R Square & Std. Error of the Estimate \\
\hline 0,20 & 0,044 & 0,038 & 28517961,85 \\
\hline
\end{tabular}

a. Predictors: (Constant), Jumlah Penduduk Miskin

b. Dependent Variable: Belanja Pendidikan

Tabel 9. Uji Koefisien Determinasi (R2)

R R Square $\begin{gathered}\text { Adjusted } \mathrm{R} \\ \text { Square }\end{gathered}$
$\begin{gathered}0,214 \quad \text { Std. Error of the Estimate } \\ \text { a. Predictors: }\end{gathered}$
$\begin{aligned} & \text { Jumlah Penduduk Miskin } \\ & \text { b. Dependent Variable: Belanja Pendidikan }\end{aligned}$
Hasil Uji $\mathrm{R}^{2}$ pada persamaan kedua menunjukkan perbedaan dengan uji $\mathrm{R}^{2}$
persamaan pertama. Dapat diketahui bahwa variabel moderasi Alokasi Dana
dengan menggunakan analisis regresi linear berganda diperoleh angka
mien determinasi dengan adjusted-R2 sebesar 0,029. Hal ini berarti bahwa
variasi variabel Belanja Pendidikan dapat dijelaskan oleh variabel perkalian
Jumlah Penduduk Miskin (JPM) dengan Alokasi Dana Desa (ADD),
gkan 96,2\% dijelaskan oleh faktor-faktor lain diluar model yang diteliti.

Tabel 10. Uji Koefisien Determinasi (R2)

\begin{tabular}{|c|c|c|c|}
\hline $\mathrm{R}$ & R Square & $\begin{array}{l}\text { Adjusted R } \\
\text { Square }\end{array}$ & Std. Error of the Estimate \\
\hline 0,22 & 0,049 & 0,032 & 28612945,68 \\
\hline \multicolumn{4}{|c|}{$\begin{array}{l}\text { a. Predictors: (Constant), JPMxDD, Dana Desa, Jumlah Penduduk } \\
\text { Miskin }\end{array}$} \\
\hline
\end{tabular}


Hasil Uji $\mathrm{R}^{2}$ pada persamaan ketiga menunjukkan perbedaa dengan uji $\mathrm{R}^{2}$ pada persamaan pertama dan kedua, diketahui bahwa variabel moderasi Dana Desa dengan menggunakan analisis regresi linear berganda diperoleh angaka koefisien determinasi dengan adjusted- R2 sebesar 0,032. Hal ini berarti bahwa 3,2\% variasi variabel Belanja Pendidikan dapat dijelaskan oleh variabel perkalian Jumlah Penduduk Miskin dengan Dana Desa (DD) sedangkan 96,8\% dijelaskan oleh faktor-faktor lain diluar model yang diteliti.

Pada Uji $\mathrm{R}^{2}$ ketiga persamaan tersebut, diperoleh kesimpulan bahwa variabel Alokasi Dana Desa (ADD) dan Dana Desa (DD) tidak mampu memoderasi hubungan antara Jumlah Penduduk Miskin dalam hubungannya dengan Belanja Pendidikan karena ketika variabel Alokasi Dana Desa dan Dana Desa dimasukkan pada persamaan kedua dan ketiga ternyata tidak mampu mempengaruhi peningkatan nilai uji $\mathrm{R}^{2}$ tersebut karena nilai uji $\mathrm{R}^{2}$ pada kedua variabel Alokasi Dana Desa dan Dana Desa lebih kecil dibandingkan dengan nilai $\mathrm{R}^{2}$ Jumlah Penduduk Miskin. Hal tersebut membuktikan bahwa Alokasi Dana Desa dan Dana Desa tidak mampu memoderasi hubungan antara Jumlah Penduduk Miskin dengan Belanja Pendidikan.

\section{Uji Signifikansi Simultan (Uji F)}

Dari hasil yang diperoleh terdapat 3 (tiga) persamaan pada Uji F yaitu dapat dilihat pada tabel di bawah ini :

\section{Tabel 11. Uji Signifikansi Simultan (Uji F)}

\begin{tabular}{|c|c|c|c|c|c|}
\hline Model & $\begin{array}{l}\text { Sum of } \\
\text { Squares }\end{array}$ & Df & $\begin{array}{l}\text { Mean } \\
\text { Square }\end{array}$ & $\mathrm{F}$ & Sig. \\
\hline Regression & $6,50 \mathrm{E}+15$ & 1 & $6,50 \mathrm{E}+15$ & 7,994 & 0,005 \\
\hline Residual & $1,42 \mathrm{E}+17$ & 174 & $8,13 \mathrm{E}+14$ & & \\
\hline Total & $1,48 \mathrm{E}+17$ & 175 & & & \\
\hline
\end{tabular}

Hasil Uji F untuk variabel Jumlah Penduduk Miskin terhadap Pengalokasian Belanja Pendidikan diketahui bahwa Fhitung $>$ Ftabel yaitu 7,994 $>2,27$ dan nilai signifikansi $=0,005<\alpha=0,05$. Hal ini menunjukan model regresi dinyatakan fit. Artinya bahwa (simultan) variabel independen Jumlah Penduduk Miskin (JPM) berpengaruh terhadap Pengalokasian Belanja Pendidikan.

Tabel 12. Hasil Uji f

\begin{tabular}{lrrrrr}
\multicolumn{1}{c}{ Model } & Sum of Squares & Df & Mean Square & F & Sig. \\
\hline Regression & $6,79 \mathrm{E}+15$ & 3 & $2,26 \mathrm{E}+15$ & 2,758 & 0,044 \\
Residual & $1,41 \mathrm{E}+17$ & 172 & $8,21 \mathrm{E}+14$ & & \\
Total & $1,48 \mathrm{E}+17$ & 175 & & & \\
\hline
\end{tabular}


a. Predictors: (Constant), JPMxADD, Alokasi Dana Desa, Jumlah Penduduk Miskin

b. Dependent Variable: Belanja Pendidikan

Hasil Uji F untuk variabel moderasi Alokasi Dana Desa diketahui bahwa Fhitung $>$ Ftabel yaitu 2,758 $>2,27$ dan nilai signifikansi $=0,044<\alpha=0,05$. Hal ini menunjukkan model regresi dinyatakan fit. Artinya bahwa (simultan) variabel independen dan moderating secara bersama-sama berpengaruh secara signifikan terhadap variabel dependent.

Tabel 13. Hasil Uji F

\begin{tabular}{lcrlll}
\hline \multicolumn{1}{c}{ Model } & \multicolumn{1}{c}{$\begin{array}{c}\text { Sum of } \\
\text { Squares }\end{array}$} & \multicolumn{1}{c}{ Df } & \multicolumn{1}{c}{ Mean } \\
Square & F & Sig. \\
\hline Regression & $7,19 \mathrm{E}+15$ & 3 & $2,40 \mathrm{E}+15$ & 2,929 & 0,035 \\
Residual & $1,41 \mathrm{E}+17$ & 172 & $8,19 \mathrm{E}+14$ & & \\
Total & $1,48 \mathrm{E}+17$ & 175 & & & \\
\hline
\end{tabular}

a. Predictors: (Constant), JPMxDD, Dana Desa, Jumlah Penduduk Miskin

b. Dependent Variable: Belanja Pendidikan

Hasil Uji F untuk variabel moderasi Dana Desa diketahui bahwa Fhitung $>$ Ftabel yaitu 2,929 $>2,27$ dan nilai signifikansi $=0,035<\alpha=0,05$. Hal ini menunjukkan model regresi dinyatakan fit. Artinya bahwa (simultan) variabel independen dan moderating secara bersama-sama berpengaruh secara signifikan terhadap variabel dependent.

\section{Uji Signifikansi Parsial (Uji t)}

Dari hasil yang diperoleh terdapat 3 (tiga) persamaan dalam Uji t. Namun dari persamaan tersebut dapat dijadikan dalam 5 model, yaitu bisa di lihat dari tabel di bawah ini :

Tabel 14. Hasil Uji t

\begin{tabular}{lrrrrr}
\hline \multirow{2}{*}{ Variabel } & \multicolumn{2}{c}{ Unstandardized Coefficients } & & \multicolumn{1}{l}{ T } & \multirow{2}{*}{ Sig. } \\
\cline { 2 - 3 } & \multicolumn{1}{c}{$\mathrm{B}$} & \multicolumn{1}{c}{ Std. Error } & & \\
\hline (Constant) & $3,02 \mathrm{E}+07$ & 4049586,339 & & 7,468 & 0,000 \\
Jumlah Penduduk Miskin & $-25038,896$ & 8855,993 & & $-2,827$ & 0,005 \\
\hline
\end{tabular}

Dependent Variable: Belanja Pendidikan

Dapat diketahui bahwa Jumlah Penduduk Miskin memiliki nilai signifikansi 0,005 lebih kecil dibandingkan level of significant yaitu sebesar 0,005 $<0,05$ dan nilai T-hitung sebesar -2,827 lebih kecil dibandingkan nilai T-tabel sebesar 1,97393. Hal ini berarti menunjukkan secara parsial variabel Jumlah Penduduk Miskin berpengaruh negatif terhadap Pengalokasian Belanja Pendidikan, maka Ha diterima. 
Tabel 15. Hasil Uji t

\begin{tabular}{|c|c|c|c|c|}
\hline \multirow[t]{2}{*}{ Variabel } & \multicolumn{2}{|c|}{ Unstandardized Coefficients } & \multirow[t]{2}{*}{$\mathrm{T}$} & \multirow[t]{2}{*}{ Sig. } \\
\hline & $\mathrm{B}$ & Std. Error & & \\
\hline (Constant) & $1,531 \mathrm{E} 7$ & 2,73E7 & 0,561 & 0,575 \\
\hline Penduduk & & & & \\
\hline Miskin & 24582,746 & 86575,455 & 0,284 & 0,777 \\
\hline Alokasi Dana Desa & 0,032 & 0,058 & 0,550 & 0,583 \\
\hline JPMxADD & 0,000 & 0,000 & $-0,578$ & 0,564 \\
\hline
\end{tabular}

Dependent Variable: Belanja Pendidikan

Dapat diketahui dari tabel di atas terdapat 2 persamaan :

Pertama, bahwa variabel Alokasi Dana Desa (ADD) memiliki nilai signifikansi 0,583 lebih besar dibandingkan level of significant yaitu sebesar 0,583 > 0,05 dan nilai T-hitung sebesar 0,55 lebih kecil dibandingkan nilai T-tabel sebesar 1,97393. Hal ini berarti menunjukkan secara parsial variabel Alokasi Dana Desa (ADD) tidak berpengaruh terhadap Pengalokasian Belanja Pendidikan, maka Ha ditolak.

Kedua, bahwa variabel moderasi Alokasi Dana Desa (ADD) memiliki nilai signifikansi 0,564 lebih besar dibandingkan level of significant yaitu sebesar 0,564 > 0,05 dan nilai T-hitung sebesar -0,578 lebih kecil dibandingkan nilai Ttabel sebesar 1,97393. Hal ini berarti menunjukkan secara parsial variabel Alokasi Dana Desa (ADD) tidak mampu memoderasi hubungan antara Jumlah Penduduk Miskin terhadap Pengalokasian Belanja Pendidikan, maka Ha ditolak

Tabel 16. Hasil Uji t

\begin{tabular}{lrrrrr}
\hline \multicolumn{2}{c}{ Variabel } & \multicolumn{2}{c}{ Unstandardized Coefficients } & \multirow{2}{*}{ T } & \multirow{2}{*}{ Sig. } \\
\cline { 3 - 4 } & \multicolumn{1}{c}{$\mathrm{B}$} & \multicolumn{1}{c}{ Std. Error } & & \\
\hline (Constant) & 160500000 & 144000000 & 1,115 & 0,266 \\
Jumlah & Penduduk & & & & \\
Miskin & $-177211,476$ & 182832,042 & $-0,969$ & 0,334 \\
Dana Desa & $-0,166$ & 0,184 & $-0,903$ & 0,368 \\
JPMxDD & 0,000 & 0,000 & 0,844 & 0,400 \\
\hline
\end{tabular}

Dependent Variable: Belanja Pendidikan.

Dari tabel di atas memilki 3 (tiga) persamaan sebagai berikut :

Pertama, dapat diketahui bahwa variabel Dana Desa (DD) memiliki nilai signifikansi 0,368 lebih besar dibandingkan level of significant yaitu sebesar 0,368 > 0,05 dan nilai T-hitung sebesar -0,903 lebih kecil dibandingkan nilai Ttabel sebesar 1,97393. Hal ini berarti menunjukkan secara parsial variabel Dana Desa (ADD) tidak berpengaruh terhadap Pengalokasian Belanja Pendidikan, maka Ha ditolak.

Kedua, dapat diketahui bahwa variabel moderasi Dana Desa (DD) memiliki nilai signifikansi 0,400 lebih besar dibandingkan level of significant yaitu sebesar 0,400 > 0,05 dan nilai T-hitung sebesar 0,844 lebih kecil dibandingkan nilai T- 
tabel sebesar 1,97393. Hal ini berarti menunjukkan secara parsial variabel Dana Desa (DD) tidak mampu memoderasi hubungan antara Jumlah Penduduk Miskin terhadap Pengalokasian Belanja Pendidikan, maka Ha ditolak.

\section{Pembahasan Hasil Analisis}

\section{Pengaruh Jumlah Penduduk Miskin terhadap Pengalokasian Belanja Pendidikan}

Berdasarkan hasil penelitian yang diperoleh, Jumlah Penduduk miskin berpengaruh negatif terhadap Belanja Pendidikan, ini dilihat dari nilai signifikansi sebesar 0,005 $<0,05$ dan nilai t hitung dan t tabel sebesar $-2,827<1,97393$, sehingga hipotesis pengaruh Jumlah Penduduk Miskin terhadap Pengalokasian Belanja Pendidikan diterima.

Penduduk Miskin yaitu penduduk yang memiliki rata-rata pengeluaran perkapita perbulan dibawah garis kemiskinan. Sedangkan Alokasi Belanja Desa Bidang Pendidikan yaitu belanja desa yang diprioritaskan untuk memenuhi kebutuhan pembangunan yang digunakan untuk menunjang pelayanan dasar terutama bidang pendidikan. Artinya bahwa semakin banyak Jumlah Penduduk Miskin maka semakin sedikit pengalokasian Belanja Pendidikan. Hal ini membuktikan bahwa alokasi belanja pendidikan untuk desa masih diterima oleh orang-orang yang kaya dibanding orang-orang miskin, kemudian yang kedua bahwa desa belum banyak menggunakan data-data penduduk miskin dari Basis Data Terpadu (BDT) dalam pengalokasian Belanja Pendidikan. Sehingga hal tersebut membuktikan bahwa alokasi belanja pendidikan belum banyak digunakan untuk penduduk miskin. Dari uraian tersebut dapat disimpulkan bahwa Jumlah Penduduk Miskin memilki pengaruh negatif terhadap Pengalokasian Belanja Pendidikan.

\section{Pengaruh Alokasi Dana Desa (ADD) terhadap pengalokasian Belanja Pendidikan}

Berdasarkan hasil penelitian yang diperoleh, menunjukkan nilai signifikansi $0,583>0,05$ dan nilai $\mathrm{t}$ hitung dan $\mathrm{t}$ tabel adalah $0,550<1,97246$. Hal ini membuktikan bahwa hipotesis pengaruh Alokasi Dana Desa (ADD) terhadap pengalokasian Belanja Pendidikan ditolak.

Alokasi Dana Desa dalam APBDes ternyata harus memperhatikan anggaran, yang dijelaskan bahwa 70\% jumlah anggaran belanja desa digunakan untuk penyelenggaraan Pemerintah Desa, pelaksanaan pembangunan desa, pembinaan kemasyarakatan desa, dan paling banyak 30\% dari jumlah anggaran belanja desa digunakan untuk penghasilan tetap, tunjangan kepala desa, dan perangkat desa, operasional pemerintah desa, tunjangan dan operasional Badan Permusyawaratan Desa (BPD). Tapi pada kenyataannya Alokasi Dana Desa (ADD) lebih difokuskan pada penghasilan tetap untuk tunjangan Kepala Desa dan Perangkat Desa. Sehingga Alokasi Dana Desa belum terfokus pada masalah Jumlah Penduduk miskin terhadap Belanja Pendidikan. Dari penjelasan di atas 
membuktikan bahwa Alokasi Dana Desa (ADD) tidak berpengaruh signifikan terhadap pengalokasian Belanja Pendidikan. Penelitian ini sejalan dengan penelitian Ummu Habibah dan Bawono (2017) dan Mardiana Luvitasari dan Bawono (2018) menyatakan bahwa ADD tidak berpengaruh signifikan terhadap Belanja Desa Bidang Pendidikan.

\section{Pengaruh Dana Desa (DD) terhadap Pengalokasian Belanja Pendidikan.}

Berdasarkan hasil penelitian yang diperoleh, menunjukkan nilai signifikansi 0,368 > 0,05 dan nilai t-hitung dan t-tabel $-0,903<1,97393$, menunjukkan hasil hipotesis pengaruh Dana Desa (DD) terhadap Pengalokasian Belanja Pendidikan ditolak.

Desa memperoleh bantuan dari pemerintah pusat dan pemerintah kabupaten/kota berupa dana desa untuk penyelenggaraan tugas-tugas pemerintahan desa dalam memberikan pelayanan publik kepada masyarakat, pemberdayaan masyarakat, dan pengelolaan pembangunan berupa dana desa yang diperoleh dari pemerintah pusat dan pemerintah kabupaten/kota. Akan tetapi Dana Desa (DD) lebih terfokus kepada infrastruktur saja bukan ke Belanja Pendidikan. Hal ini dikarenakan untuk mengejar pembangunan fisik desa yang telah tertinggal, sehingga alokasi untuk Belanja Pendidikan belum bisa teralokasikan. Dari pembahasan di atas bahwa Dana Desa (DD) tidak berpengaruh signifikan terhadap Pengalokasian Belanja Pendidikan. Akan tetapi, penelitian ini tidak sejalan dengan penelitian Ayu dan Bawono (2018) yang menyatakan bahwa Dana Desa secara parsial berpengaruh signifikan dan positif terhadap Belanja Desa secara statistik.

\section{Pengaruh Alokasi Dana Desa (ADD) memoderasi hubungan antara Jumlah Penduduk Miskin dengan Pengalokasian Belanja Pendidikan.}

Berdasarkan hasil penelitian yang diperoleh, menunjukkan bahwa Alokasi Dana Desa (ADD) tidak mampu memoderasi hubungan antara jumlah Penduduk Miskin dengam Alokasi Belanja Pendidikan. Hal ini dibuktikan dengan nilai signifikan 0,564 > 0,05 dan nilai t hitung dan t tabel sebesar -0,578<1,97393, sehingga hipotesis pengaruh Alokasi Dana Desa (ADD) memoderasi hubungan antara Jumlah Penduduk Miskin dengan Pengalokasian Belanja Pendidikan ditolak.

Berdasarkan PP Nomor 47 Tahun 2015 menyatakan bahwa Alokasi Dana Desa selanjutnya disingkat ADD, adalah dana perimbangan yang diterima Kabupaten/Kota dalam anggaran pendapatan dan belanja daerah Kabupaten atau kota setelah dikurangi Dana Alokasi Khusus. Alokasi dana desa berasal dari APBD yang bersumber dari dana perimbangan yang diterima Kabupaten/Kota untuk desa paling sedikit 10\%. Menurut Undang-Undang No. 6 Tahun 2014 tetang Desa bahwa penghasilan tetap Kepala Desa dan juga Perangkat Desa berasal dari dana perimbangan yang diperoleh dari APBN kemudian diterima oleh Kabupaten/Kota dan ditetapkan Anggaran Pendapatan Belanja Daerah 
Kabupaten/Kota. Terlihat dari penjelasan di atas, bahwa selama ini Alokasi Dana Desa (ADD) tidak bisa mensuport hubungan antara Jumlah Penduduk Miskin dengan pengalokasian Belanja Pendidikan karena ADD lebih fokus pada penghasilan tetap (SilTap) untuk Kepala Desa dan juga Perangkat Desa. Maka dari itu Alokasi Dana Desa tidak bisa memoderasi hubungan antara Alokasi Dana Desa (ADD) dengan pengalokasian Belanja Pendidikan.

\section{Pengaruh Dana Desa (DD) memoderasi hubungan antara Jumlah Penduduk Miskin dengan Pengalokasian Belanja Pendidikan.}

Berdasarkan hasil penelitian yang diperoleh, terlihat bahwa nilai signifikansi $0,400>0,05$ dan nilai $t$ hitung dan $t$ tabel $0,844<1,97393$. Hal tersebut menunjukkan bahwa hipotesis pengatuh Dana Desa (DD) memoderasi hubungan antara Jumlah Penduduk miskin dengan Pengalokasian Belanja Pendidikan ditolak.

Hal tersebut membuktikan bahwa ternyata Dana Desa (DD) tidak mampu memoderasi hubungan antara Jumlah Penduduk Miskin dengan Alokasi Belanja Pendidikan. Permendes No.4 Tahun 2017 menyatakan bahwa secara umum prioritas penggunaan Dana Desa (DD) digunakan untuk membiayai pelaksanaan program dan kegiatan di bidang Pembangunan Desa dan Pemberdayaan Masyarakat Desa. Dalam pelaksanaan kegiatan di bidang Pemberdayaan Masyarakat salah satunya yaitu dengan meningkatkan kesejahteraan masyarakat melalui program pendidikan. Dengan adanya program pendidikan diharapkan mampu mengurangi jumlah penduduk miskin khususnya Kabupaten Wonogiri. Tapi pada kenyataannya pengalokasian Belanja Pendidikan bagi desa masih relatif kecil karena Dana Desa (DD) lebih banyak digunakan untuk pembangunan fisik semata belum kepada pembangunan Belanja Pendidikan khususnya pemberian desa kepada masyarakat miskin. Sehingga disimpulkan bahwa Dana Desa (DD) tidak bisa dijadikan variabel moderating dalam penelitian ini.

\section{KESIMPULAN, KETERBATASAN DAN SARAN}

Berdasarkan hasill hipotesis secara parsial menunjukkan bahwa variabel Jumlah Penduduk Miskin memiliki pengaruh negatif terhadap Pengalokasian Belanja Pendidikan Sedangkan untuk variabel Alokasi Dana Desa (ADD) dan Dana Desa (DD) tidak berpengaruh signifikan terhadap Pengalokasian Belanja Pendidikan dan untuk variabel moderasi Alokasi Dana Desa (ADD) dan Dana Desa (DD) tidak dapat memoderasi hubungan antara Jumlah Penduduk Miskin terhadap Alokasi Belanja Pendidikan.

Berdasarkan simpulan hasil penelitian di atas, penelitian ini masih banyak memiliki keterbatasan antara lain: Beberapa desa tidak mengumpulkan Laporan Realisasi Anggaran (LRA) atas APBDesnya, masih banyak desa yang tidak melakukan belanja prioritas dalam bidang pendidikan, beberapa nama desa tidak sesuai dalam data Laporan Realisasi Anggaran (LRA) dengan data desa pada 
Basis Data Terpadu TNP2K, selanjutnya penelitian ini hanya mengguankan 1 (satu) tahun anggaran yaitu pada tahun 2017, dan penelitian ini masih banyak kekurangan karena belum banyaknya penelitian yang menggunakan variabel moderating pada level desa.

Berdasarkan simpulan dan keterbatasan di atas, maka peneliti ingin memberikan saran untuk penelitian selanjutnya. Saran yang pertama yaitu sebaiknya penelitian selanjutnya menggunakan data Laporan Realisasi Anggaran lebih dari 1 (satu) tahun supaya data yang diperlukan lebih lengkap. Saran kedua yaitu sebaiknya penelitian selanjutnya mengguankan variabel lainnya terutama pada variabel independen supaya mengetahui faktor lainnya yang berpengaruh terhadap Alokasi Belanja Desa.

\section{REFERENSI}

Darmawan, Deni. 2013. Metode Penelitian Kuantitatif. Bandung: PT Remaja Rosdakarya Economics”. Jakarta: Salemba Empat. Edisi 15. Erlangga.

Ghozali, Imam. 2011. Aplikasi Analisis Multivariate Dengan Program IBM SPSS 19 (edisi kelima). Semarang : Universitas Diponegoro.

Habibah, Ummu dan Bawono. 2017. “Analisis Pengaruh Pendapatan Asli Desa (PADes), Dana Desa (DD), Alokasi Dana Desa (ADD), dan Bagi Hasil Pajak dan Retribusi (BHPR) Terhadap Belanja Desa Bidang Pendidikan (Studi Empiris di Seluruh Desa Se-Kabupaten Sukoharjo)". Surakarta: Fakultas Ekonomi Dan Bisnis, Universitas Muhammadiyah Surakarta.

Janah, Ayu Miftakhul. 2018. "Analisis Flypaper Effect pada Pendapatan Asli Desa (PaDesa), Alokasi Dana Desa (ADD), dan Dana Desa (DD) terhadap Belanja Desa Tahun 2017 (Studi Empiris di Desa-Desa Se-Kabupaten Wonogiri)". Surakarta: Fakultas Ekonomi Dan Bisnis, Universitas Muhammadiyah Surakarta.

Kuncoro, Mudrajat. 2013. Metode Riset Untuk bisnis dan ekonomi.Jakarta: hlm.145

Lind, Marchal, and Wathen. 2014. "Statistical Techniques In Business and Economics”. Jakarta: Salemba Empat. Edisi 15 : hlm.300-301.

Luvy, Mardiana dan Bawono. 2018. "Analisis Pengaruh Pendapatan Asli Desa (PADes), Dana Desa (DD), Alokasi Dana Desa (ADD), Bagi Hasil Pajak dan Retribusi (BHPR), dan Jumlah Murid PAUD Terhadap Alokasi Belanja Desa Bidang Pendidikan (Studi Empiris di Desa-Desa Se-Kabupaten Wonogiri)". Surakarta: Fakultas Ekonomi Dan Bisnis, Universitas Muhammadiyah Surakarta.

Muliza, dkk. 2017. "Analisis Pengaruh Belanja Pendidikan, Belanja Kesehatan,Tingkat kemiskinan dan PDRB terhadap IPM di Provinsi Aceh". 
Jurnal Perspektif Ekonomi Darussalam, Vol. 3. No. 1. ISSN. 2502-6976. FEB UNSYIAH.

Nur, Muhammad. 2015. "Pengaruh Pendapatan Asli Daerah, Dana Alokasi Umum, dan Dana Alokasi Khusus terhadap Belanja Daerah di Sulawesi Selatan". ASSETS, Vol. 5. No. 1. Hal: 78-88.

Pelealu, Andreas Marzel. 2013. "Pengaruh Dana Alokasi Khusus (DAK) dan Pendapatan Asli Daerah (PAD) Terhadap Belanja Modal Pemerintah Kota Manado Tahun 2003-2012”. Jurnal EMBA, Vol 1, No 4, Desember 2013, ISSN: 2303-1174 hal 1189-1197.

Peraturan Pemerintah No. 47 Tahun 2015 Tentang Peraturan Pelaksanaan UU No 6 Tahun 2014 Tentang Desa.

Peraturan Pemerintah No. 43 Tahun 2014 Tentang Peraturan Pelaksanaan Undang-Undang Nomor 6 Tahun 2014 Tentang Desa

Permendagri No. 113 Tahun 2014, Tentang Pengelolaan Keuangan Desa.

Permendes No. 4 Tahun 2017 Tentang Penetapan Prioritas Penggunaan Dana Desa Tahun 2017.

Sari, Ramadha Puspita. 2014. "Pengaruh Pendapatan Asli Daerah (PAD), Dana Alokasi Umum (DAU) dan Dana Alokasi Khusus (DAK) terhadap Belanja Daerah (Studi Kasus pada Pemerintah Daerah Kabupaten/Kota di Provinsi Jawa Tengahdan DIY)" Yogyakarta: Universitas PGRI Yogyakarta.

Siburian, Edita D.B, dkk. 2014. "Peranan Anggaran Pendapatan dan Belanja Desa Dalam Pengembangan Wilayah Perdesaan Di Kabupaten Serdang Bedagai”. Jurnal Ekonomi, Vol 17, No 2, April 2014.

Syamsi, Syahrul. 2014. "Partisipasi Masyarakat Dalam Mengontrol Penggunaan Anggaran Dana Desa”. Jurnal Ilmu Sosial dan Ilmu Politik. Vol. 3. No. 1.

Undang-Undang No. 23 Tahun 2014 Tentang Pemerintah Daerah.

Undang-Undang No. 6 Tahun 2014 Tentang Desa.

https://wonogirikab.bps.go.id/. 